\title{
Reproduction of cutlassfishes Trichiurus spp. from the South China Sea
}

\author{
K. Y. Kwok, I.-H. Ni* \\ Department of Biology, Hong Kong University of Science \& Technology, Hong Kong SAR, China
}

\begin{abstract}
Cutlassfishes, Trichiurus Linnaeus, 1758, are the most important commercial marine fish species of China in terms of weight and they are found in all Chinese waters. However, no study has been conducted on the populations of Trichiurus in the South China Sea. The aim of this study was to investigate the reproduction of the populations of Trichiurus spp. in the South China Sea. In a 12 mo sampling period between December 1996 and November 1997, 1495 specimens of $T$. lepturus and $T$. nanhaiensis were collected from Hong Kong coastal waters. Spawning period and reproductive cycle were studied by checking the temporal profile of the Relative Gonadal Index/Gonosomatic Index, and by examining ovaries macroscopically and whole oocytes microscopically. All 3 methods provided similar results: the spawning periods of $T$. lepturus and T. nanhaiensis were March to June and April to August, respectively. Both species were found to practice group-synchronous spawning and mature females are capable of spawning more than once each spawning season. The mean preanal lengths at sexual maturity of $T$. lepturus and $T$. nanhaiensis females were 255 and $282 \mathrm{~mm}$ respectively. The sex ratios of both species were significantly different from 1:1 among different sampling months, and different age and size ranges.
\end{abstract}

KEY WORDS: Cutlassfish - Reproduction - Spawning season $\cdot$ Size at maturity $\cdot$ Sex ratio

\section{INTRODUCTION}

Cutlassfish, Trichiurus lepturus Linnaeus, 1758 is caught from all Chinese seas (Jiang et al. 1991) and is the most important commercial marine fish species of China in terms of weight (Luo 1991). Reproduction and recruitment are the major events in the life history of the fish and also are the main determinants of yield (King 1995). Numerous investigations covering most aspects of the reproduction of $T$. lepturus have been carried out in the past few decades (Table 1). However, research has focused on northern (East China Sea, Yellow Sea and Bo Hail populations, and no study has been conducted on the South China Sea populations.

Trichiurus lepturus only spawns once in the Yellow Sea, from May to July (Chu 1982, cited in Lin 1985), while it has a very long spawning period, from April to October, in the East China Sea (Li 1982, Luo et al. 1982,

\footnotetext{
-Addressee for correspondence. E-mail: boniih@ust.hk
}

1983). The age at sexual maturity $\left(T_{\mathrm{m}}\right)$ of the Yellow Sea and the Bo Hai populations was about 3 yr old for females in the 1960s (Lin 1985). For the East China Sea female cutlassfish in 1963-1964, the $T_{\mathrm{m}}$ was about $1 \mathrm{yr}$ old with the size being $240 \mathrm{~mm}$ (preanal length), which then decreased in 1979-1980 to about 7 mo old with the size being $200 \mathrm{~mm}$ (Luo et al. 1983). Similarly, the biological minimum size of females at first maturity was $238 \mathrm{~mm}$ in 1962 (Lin 1982), which decreased to about $170-180 \mathrm{~mm}$ in 1979-1980 (Luo et al. 1983).

The situation of cutlassfish populations in the South China Sea is further complicated by the fact that there are 3 species - Trichiurus lepturus, $T$. nanhaiensis Wang \& $\mathrm{Xu}$ in Wang et al. (1992) and $T$. brevis Wang \& You in Wang et al. (1992) -instead of $1-T$ lepturus - as in the northern seas of China (Wang et al. 1992, 1993, 1994). Previous studies have shown that populations in the Bo Hai, the Yellow Sea and the East China Sea have suffered from serious overfishing (Lin 1985, Ye \& Rosenberg 1991, Xu et al. 1994). The Bo Hai and the Yellow Sea cutlassfish fisheries have collasped 
Table 1. Summary of reproductive studies of Trichiurus lepturus

\begin{tabular}{|c|c|c|c|c|c|}
\hline Country & Study area & $\begin{array}{l}\text { Study } \\
\text { period }\end{array}$ & Study items & Methods & Source \\
\hline Chind & $\begin{array}{l}\text { Yellow Sed } \\
\text { and Bo Hai }\end{array}$ & $1958-64$ & Egg and larva development & $\begin{array}{l}\text { Artificial fertilization and } \\
\text { plankton net collection }\end{array}$ & Sha et al. (1981) \\
\hline China & $\begin{array}{l}\text { East China Sea, } \\
\text { Yellow Sea } \\
\text { and Bo Hai }\end{array}$ & $1952-57$ & $\begin{array}{l}\text { Spawning ground and spawning } \\
\text { season, age at sexual maturity, oo- } \\
\text { cyte diameter and maturation stage }\end{array}$ & Gonosomatic index, survey & Misu (1964) \\
\hline China & East China Sea & $1963-64$ & Fecundity & & Qiu \& Jiang (1965) \\
\hline China & East China Sea & 1976 & Fecundity & & Li (1983) \\
\hline China & East China Sea & $1976-79$ & Fecundity & & Li (1986) \\
\hline China & East China Sea & $1977-79$ & $\begin{array}{l}\text { Maturation stage and spawning } \\
\text { season, oocyte diameter }\end{array}$ & $\begin{array}{l}\text { Gonosomatic index, macro- } \\
\text { scopic and microscopic } \\
\text { examination }\end{array}$ & Li (1982) \\
\hline China & $\begin{array}{l}\text { East China Sea } \\
\text { (north) }\end{array}$ & $1977-80$ & Spawning season & $\begin{array}{l}\text { Gonosomatic index and first } \\
\text { otolith annular radius }\end{array}$ & Luo et al. (1982) \\
\hline China & East China Sea & $1979-80$ & $\begin{array}{l}\text { Maturation stage and spawning } \\
\text { season, oocyte diameter, size at } \\
\text { sexual maturity }\end{array}$ & $\begin{array}{l}\text { Macroscopic and microscopic } \\
\text { examination }\end{array}$ & Luo et al. (1983) \\
\hline China & East China Sea & $1960-80$ & Prematuration & & Lin (1982) \\
\hline China & East China Sea & $1980-81$ & $\begin{array}{l}\text { Maturation stage and spawning } \\
\text { season }\end{array}$ & Microscopic examination & Gong et al. (1984) \\
\hline China & East China Sea & $1976-79$ & Fecundity & & $\operatorname{Li}(1988)$ \\
\hline Japan & Suruga Bay & 1965 & $\begin{array}{l}\text { Spawning season and maturation } \\
\text { stage }\end{array}$ & $\begin{array}{l}\text { Gonosomatic index, } \\
\text { ova diameter }\end{array}$ & Kosaka et al. (1967) \\
\hline Japan & Kii Channel & $1972-74$ & Spawning season & Gonosomatic index & Sakamoto $(1976)$ \\
\hline Japan & Kumano-Nada & $1978-79$ & $\begin{array}{l}\text { Sex ratio, spawning season, } \\
\text { fecundity, size at sexual maturity }\end{array}$ & $\begin{array}{l}\text { Gonosomatic index } \\
\text { and oocyte diameter }\end{array}$ & $\begin{array}{l}\text { Suzuki \& Kimura } \\
(1980)\end{array}$ \\
\hline Japan & Wakasa Bay & $1981-83$ & Sex ratio and spawning season & Gonosomatic index & $\begin{array}{l}\text { Munekiyo \& } \\
\text { Kuwahara (1984a) }\end{array}$ \\
\hline Japan & Wakasa Bay & 1982 & $\begin{array}{l}\text { Size at sexual maturity and } \\
\text { fecundity }\end{array}$ & & $\begin{array}{l}\text { Munekiyo \& } \\
\text { Kuwahara (1988) }\end{array}$ \\
\hline Japan & Tsushima waters & $1967-87$ & Spawning season & Gonosomatic index & Hanabuchi (1989) \\
\hline Japan & Ariake Sound & 1961 & $\begin{array}{l}\text { Spawning season, egg and larva } \\
\text { development }\end{array}$ & $\begin{array}{l}\text { Macroscopic examination, } \\
\text { artificial fertilization }\end{array}$ & Tsukahara (1961) \\
\hline Korea & $\begin{array}{l}\text { South-western } \\
\text { waters }\end{array}$ & $1965-70$ & $\begin{array}{l}\text { Spawning season and area, age } \\
\text { at sexual maturity }\end{array}$ & $\begin{array}{l}\text { Eggs and larvae survey, gono- } \\
\text { somatic index, egg diameter }\end{array}$ & $\begin{array}{l}\text { Park \& Hwang } \\
\text { (1978) }\end{array}$ \\
\hline
\end{tabular}

and could only be harvested as bycatch (Lin 1985). However, the situation of the populations in the South China Sea remains unclear.

To evaluate the validity of the Gonosomatic Index (GSI) is crucial and, in fact, a prerequisite in employing this method to study reproduction (Devlaming et al. 1982). However, this has not been addressed in previous studies (Misu 1964, Kosaka et al. 1967. Sakamoto 1976, Park \& Hwang 1978, Suzuki \& Kimura 1980, Li 1982, Luo et al. 1982, Munekiyo \& Kuwahara 1984a, Hanabuchi 1989). In this study, gonad indices are validated and are utilised to estimate spawning periods.

In order to reveal the vital biological parameters of the South China Sea cutlassfishes and to prevent and/or mitigate the possible over-exploitation, a thorough study in the South China Sea is necessary. The objective of this study is to describe the reproductive cycle and to estimate the spawning period, the age and length at sexual maturity, and the sex ratios of cutlassfishes Trichiurus spp. from the South China Sea. Hopefully, the findings of this study will contribute to the development of an ecologically sustainable cutlassfish fishery as well as stimulating relevant studies of the natural resources in the South China Sea.

\section{MATERIALS AND METHODS}

In the 12 mo (December 1996 to November 1997) sampling period, 960 Trichiurus lepturus and $535 \mathrm{~T}$. nanhaiensis were collected from commercial catches within Hong Kong coastal waters (about 12 nautical miles). Fishing methods included longlining, purse seining and bottom trawling. The freshly caught specimens were chilled onboard with crushed ice and transported to the laboratory. Specimens were identi- 
fied using the diagnostic key of Wang et al. (1992, 1993); if frontal bone can be split laterally it is $T$. lepturus, otherwise it is $T$. nanhaiensis. Preanal lengths (from the tip of the lower jaw with the mouth closed to the middle of the anus; PL) were measured to the nearest $\mathrm{mm}$. Bodies (gutted and ungutted) and ovaries were blotted dry and weighed to the nearest $0.01 \mathrm{~g}$.

Reproductive cycle and spawning period. Three different examination methods were employed: (1) ovary examination, (2) whole oocyte examination, and (3) gonad indices (gonosomatic index and relative gonadal index).

(1) Ovaries were macroscopically staged using a scale modified from Li (1982), Luo et al. (1983) and $\mathrm{Ni}$ \& Templeman (1985) (Table 2). Stage of ovarian maturity was assessed according to color, size and shape. The accuracy of the macroscopic staging of ovarian maturity was validated by comparing it with the findings from whole oocyte examination. The monthly profile of ovarian maturity was used to estimate the spawning period (Luo et al. 1983).

(2) Fresh, unfixed oocytes were examined microscopically shortly after dissection. Oocytes that had already undergone post-mortem autolysis were not used in the analysis. Oocytes were examined under a compound microscope at 40 to $100 \times$ and staged using the scale adapted from Li (1982), Luo et al. (1983), and Gong et al. (1984) (Table 2). The maturity stage of each ovary was classified according to the oocyte stage found in more than $50 \%$ of the ovarian area (adapted from Gong et al, 1984).

Preliminary analysis indicated that ovaries were at the same maturity stage throughout the length of the ovary. Subsequently, only oocytes from the central section of each ovary were retrieved and investigated. Monthly profiles of the stages of oocyte maturity were used to estimate the spawning period (Luo et al. 1983). Since Stage 3B oocytes were fully mature, they were grouped with Stage 4 oocytes as 'mature and spawning' whereas Stage 5 (spent) and Stage 6 (atresia) were grouped as 'spent'.

(3) Gonosomatic index (GSI = gonad wt/gutted wt $\times$ 1000) was used to quantify reproductive condition in Trichiurus lepturus (Table 1). However, the validity of GSI has not been evaluated in previous studies. The most important assumption of GSI is that it is independent of body size (DeVlaming et al. 1982). Pinpointing this problem, Erickson et al. (1985) introduced a new index called Relative Conadal Index: RGI $=\alpha_{i}=G / W^{\beta_{1}}$, where $G$ is gonad weight, $W$ is gutted weight or other body measurements (e.g. body length), and $\alpha_{1}, \beta_{1}$ are the parameters of gonadal maturity stage i. $\alpha_{1}$ and $\beta_{\mathrm{i}}$

Table 2. Macroscopic characteristics of ovaries and microscopic characteristics of whole oocytes of cutlassfishes, Trichiurus spp.

\begin{tabular}{|c|c|c|c|}
\hline Stage & Classification & Ovary appearance & Oocyte microscopic appearance \\
\hline 1 & Immature & $\begin{array}{l}\text { Ovarian wall transparent, no egg can be } \\
\text { seen. Ovary thread-like and short }\end{array}$ & $\begin{array}{l}\text { Oocyte transparent and irregular or round shape. The } \\
\text { nucleus occupies the bulk of the cell and oocyte is } \\
\text { surrounded by a thin follicle layer }\end{array}$ \\
\hline $2 \mathrm{~A}$ & Developing I & $\begin{array}{l}\text { Ovary color cream to yellow, eggs, if } \\
\text { present. hard to seen. Ovary about } 50 \% \\
\text { length of ventral cavity }\end{array}$ & $\begin{array}{l}\text { Oocyte is round; multiple nucleoli appear; lipid bodies } \\
\text { appear around the nucleus while yolk vesicles are } \\
\text { observed in the peripheral region during the initial } \\
\text { stage. In later stage, yolk granules start to develop } \\
\text { and are difficult to see }\end{array}$ \\
\hline $2 \mathrm{~B}$ & Developing II & & $\begin{array}{l}\text { Vitellogenic oocyte: yolk vesicles decrease in number } \\
\text { while yolk granules increase in size and number, and } \\
\text { follicular layers increase in thickness }\end{array}$ \\
\hline $3 \mathrm{~A}$ & Maturing I & $\begin{array}{l}\text { Ovary yellow to orange color, opaque } \\
\text { oocytes visible through epithelium. Ovary } \\
\text { about } 60-70 \% \text { length of ventral cavity }\end{array}$ & $\begin{array}{l}\text { Oocytes full of yolk granules which then coalesce to } \\
\text { form yolk globules. Yolk globules start to aggregate } \\
\text { at the central area and conceal the nucleus }\end{array}$ \\
\hline 3B & Maturing II & & $\begin{array}{l}\text { Yolk globules start to fuse together and oocytes } \\
\text { become more transparent. Lipid bodies start to fuse to } \\
\text { form larger droplets and become fewer. The nucleus } \\
\text { migrates to the periphery }\end{array}$ \\
\hline 4 & $\begin{array}{l}\text { Spawning } \\
\text { (ripe) }\end{array}$ & $\begin{array}{l}\text { Ovary swollen, filled. with hydrated } \\
\text { oocytes visible through epithelium. Eggs } \\
\text { in the oviduct transparent, can be } \\
\text { extruded with gentle pressure. Ovary } \\
\text { about } 80 \% \text { length of ventral cavity }\end{array}$ & $\begin{array}{l}\text { Lipid bodies fuse with one another and become one } \\
\text { large oil droplet. Nuclear envelope breaks down } \\
\text { (germinal vesicle breakdown) and oocytes increase in } \\
\text { transparency. Hydrated oocytes reach the maximum } \\
\text { size and ready to spawn }\end{array}$ \\
\hline 5 & Spent & $\begin{array}{l}\text { Ovary translucent with pale violet color. } \\
\text { Ovary shrunk and flaccid }\end{array}$ & Empty follicles (post-ovulatory follicles) are present \\
\hline 6 & Atresia & & $\begin{array}{l}\text { Irregular shape, separation of the different follicular } \\
\text { layers, change in appearance of the yolk, and break- } \\
\text { down of the outer membranes }\end{array}$ \\
\hline
\end{tabular}


can be estimated by applying least squares regression for the log-transformed model:

$$
\ln (G)=\beta_{1} \ln (W)+\ln \left(\alpha_{i}\right)
$$

Based on t-test results, $\beta$ values for most ovarian maturity stages of Trichiurus lepturus and T. nanhaiensis (based on whole oocyte examination) were significantly different from 1 . This indicates that GSI was not independent of body size and therefore was not applicable to the study of reproductive condition. The slopes of the log transformed model were homogenous among maturity stages of $T$. lepturus (ANCOVA, $F_{6,609}=1.682, p>0.12$ ). Hence, a pooled slope was estimated $(\beta=1.470)$. The intercepts among different maturity stages of $T$. lepturus proved to be significantly different (ANCOVA, $F_{6,615}=449.326, \mathrm{p}<0.001$ ). If both slopes and intercepts are homogenous among different maturity stages, it indicates either a constant reproductive condition (gonadal weight or stage of development) or erroneous staging of gonadal development (Erickson et al. 1985). Thus, RGI $=G / W^{1.470} \times 1000$ was used for $T$. lepturus to investigate the monthly variation of ovarian development

The slopes of the log transformed model differed significantly among maturity stages of Trichiurus nanhaiensis (ANCOVA, $F_{5,208}=7.564, p<0.001$ ). When preanal length was used to replace the gutted weight in the regression, the results were similar. Hence, RGI was not applicable for the collected specimens of $T$. nanhaiensis and GSI was chosen instead. The use of GSI might be justified by the fact that $75 \%$ of the specimens were within a reasonably narrow size range $(\mathrm{PL}=330-440 \mathrm{~mm})$ and $98 \%$ of the specimens were larger than the mean size at sexual maturity.

For all 3 methods mentioned above, only females equal to or larger than the size at sexual maturity were included in the analyses.

Size at sexual maturity. The size at sexual maturity $\left(L_{m}\right)$ is defined as the length at which $50 \%$ of the fish are sexually mature ( $\mathrm{Ni} \&$ Sandeman 1984) and it can be derived by fitting a logistic curve to the proportion of sexually mature individuals by length: $P=$ $1 /\left\{1+\mathrm{e}^{\left.\mid-f\left(L-L_{m}\right)\right\}}\right.$ (King 1995). The equation was transformed to:

$$
\ln [(1-P) / P]=r L_{\mathrm{m}}-r L_{1}
$$

where $P$ is the proportion of sexually mature individuals (Stage 3A or above were considered as mature), $r$ is the slope of the curve, $L$ is the preanal length in $\mathrm{mm}$ and $L_{\mathrm{m}}$ is the mean preanal length at sexual maturity, which corresponds to $P=0.5$. Coefficients were estimated by plotting $\ln [(1-P) / P]$ against $L_{i}$ then $L_{m}=$ intercept/slope $(r)$. Females were grouped in $10 \mathrm{~mm}$ groups for estimating size at sexual maturity. For Trichiurus lepturus, only specimens caught during the reproductively active season (February to July) were included. However, due to scarcity of specimens of $T$. nanhaiensis ( $\mathrm{n}=249$ ), the data from the entire year was used.

Sex and species ratio. A chi-square test was employed to study the temporal variation of sex ratio and sex ratio among different age and size ranges. For the temporal variation investigation, only specimens equal to or larger than the size at sexual maturity were included since juveniles were not collected in all months. For the analysis of sex ratio among different size ranges, specimens were grouped in $50 \mathrm{~mm}$ groups (Hanabuchi 1989). The ratio between the 2 species was also investigated.

\section{RESULTS}

\section{Reproductive cycle and spawning period}

Ovaries of both species at the same maturity stage are similar in appearance and size. Ovaries are paired and elongate in shape and attached to the body cavity by the dorsal mesentery. Left and right lobes are of equal length and are fused together but are separated laterally by a membrane. The monthly variation in macroscopic ovarian stage is illustrated in Fig. 1 Trichiurus lepturus spawned almost all year round and peaked from March to June while $T$. nanhaiensis

\section{(A) T. lepturus}

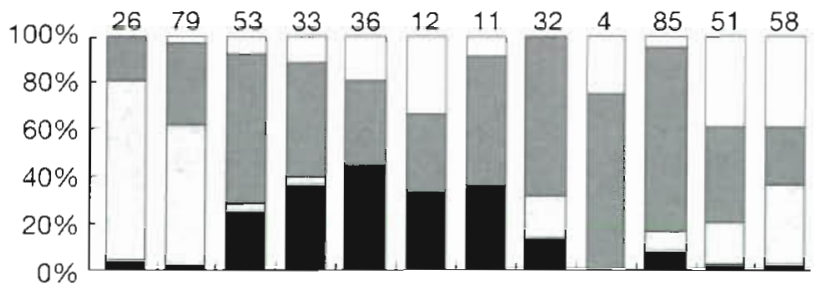

\section{(B) T. nanhaiensis}

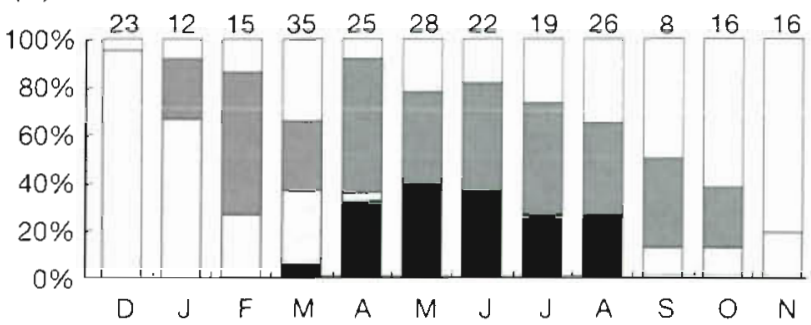

Fig. 1. Monthly variation in macroscopic ovarian stage of cutlassfishes Trichiurus spp. The $x$-axes are months of collection, $y$-axes are percentage of ovaries at different maturity stages, numbers on the top are sample sizes. Maturity stages: black, Stage 4 (ready to spawn): light grey, Stage 1-2 (previtellogenic and early vitellogenic); dark grey, Stage 3 (advanced vitellogenuc); white, Stage 5 (spent). Maturity stages follow Table 2 
spawned from March to August and peaked from April to August. Agreement between macroscopic gonad staging and whole oocyte staging was $84.3 \%$ for $T$. lepturus and $85.0 \%$ for $T$. nanhaiensis. Most of the discrepancy came from staging of spent gonads

Whole oocytes were examined microscopically and the characteristics of each maturity stage are listed below:

Stage 1: Oocytes are transparent and pear- or roundshaped. The nucleus occupies most of the cell and a thin follicle layer surrounds the oocyte. During this stage both the chromatin nuclear and early perinucleolar stages occur. No Stage 1 oocytes were found in Trichiurus nanhaiensis during the collection period.

Stage 2A (Fig, 2A): Oocytes are round and have multiple nucleoli. The most obvious feature is perinucleolar nuclei. Both lipid bodies and the yolk vesicles (cortical alveoli) are difficult to identify. During this stage both the late perinucleolar stage and the yolk vesicle stage occur.
Stage 2B (Fig. 2B): Yolk granules are found in peripheral regions and appear as small opaque spheres when examined under a light microscope. This marks the beginning of vitellogenesis. Follicular layers composed of theca cell layer, granulosa cell layer and zona radiata increase in thickness. Nuclei are no longer observed because the yolk granules conceal them.

Stage 3A (Fig. 2C): As more yolk granules are incorporated, they coalesce to form yolk globules. Yolk globules then aggregate and occupy the entire central area of the oocytes. Follicular layers further increase in thickness.

Stage 3B (Fig. 2D): Centripetal yolk globules start to fuse together and oocytes become more transparent. Lipid bodies begin to fuse to form larger droplets and resulting in few numbers.

Stage 4 (Fig. 2E): Lipid bodies fuse with one another to form one large oil droplet. Oocytes become transparent and nuclei disappear (germinal vesicles breakdown). Hydrated oocytes reach maximum size and are ready to be spawned.
Fig. 2. Whole oocytes of cutlassfishes Trichiurus spp. at different stages of maturity. (A) Previtellogenic stage. Scale bar = $100 \mu \mathrm{m}(200 \times)$. (B) Early vitellogenic stage. Scale bar $=200 \mu \mathrm{m}(30 \times) .(\mathrm{C})$ Late vitellogenic stage. Scale bar $=200 \mu \mathrm{m}(40 \times)$. (D) Mature. Scale bar $=$ $500 \mu \mathrm{m}(20 \times)$. (E) Ripe. Scale bar $=500 \mu \mathrm{m}$ $(30 \times)$. (F) Atresia. Scale bar $=500 \mu \mathrm{m}(30 \times)$ Maturity stages follow Table 2
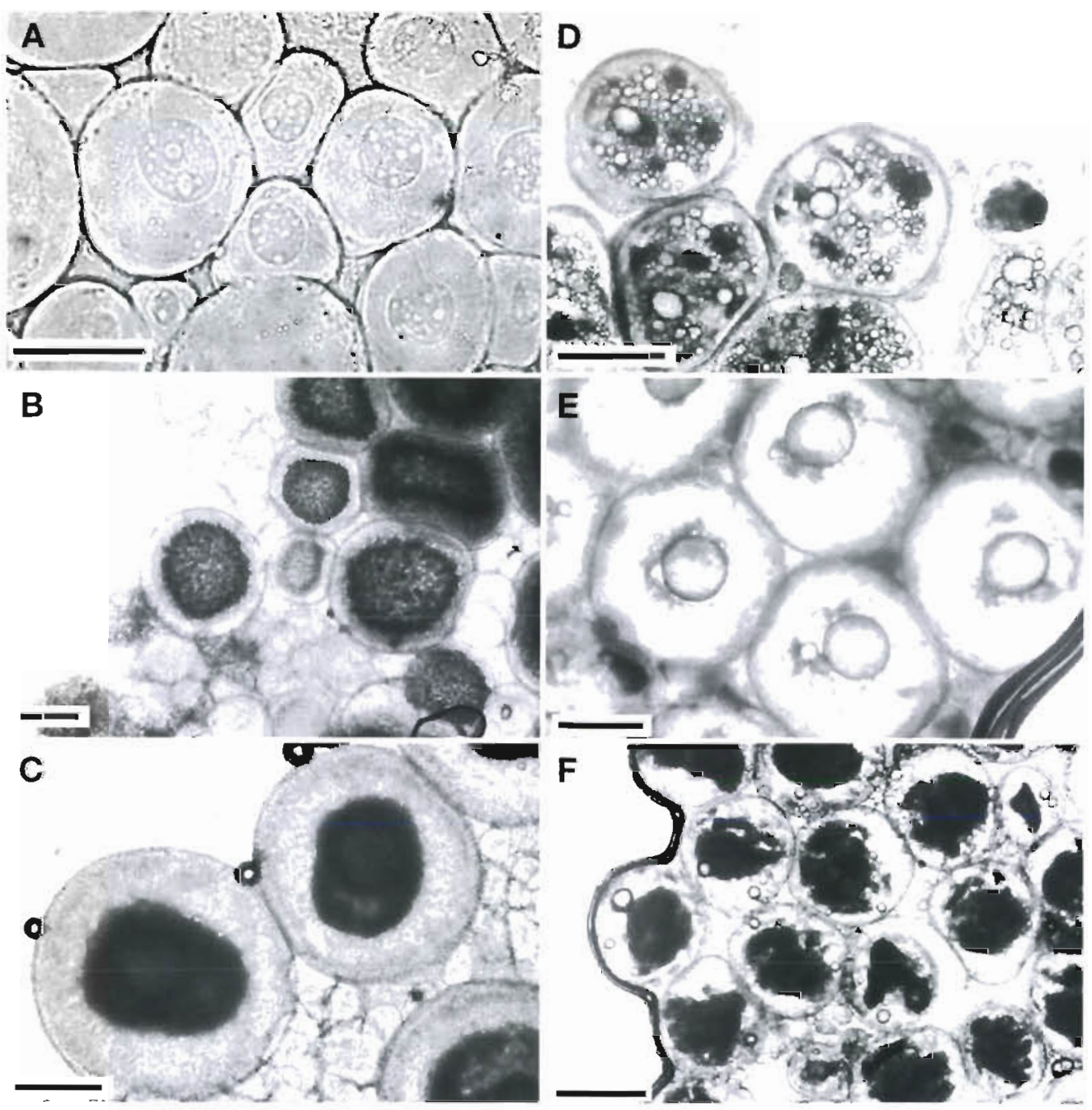
Stage 5: Empty follicles occurring after spawning are difficult to identify by whole oocyte examination because of the rapid degeneration of post-ovulatory follicles. During early months of spawning, April to June, spent ovaries staged by ovary macroscopic examination contained oocytes at less advanced maturity stages. In this case, the ovaries were staged according to those normal oocytes. However, approaching the end of the spawning period, spent ovaries consisted mainly of atresic oocytes.

Stage 6 (Fig. 2F): Atresia (degeneration) seemed to only affect vitellogenic oocytes, i.e. oocytes at Stage 2B-3B. Atresic oocytes are characterized by separation of different follicular layers (e.g. zona radiata separates from granulosa cell layer), irregular shapes of oocytes, change in yolk appearances, and the breakdown of outer membranes.

In most cases, at least 2 populations of oocytes could be distinguished-a synchronous population of larger oocytes (more advanced in maturity) and a heterogeneous population consisting of oocytes at different and less advanced stages of maturity. This indicates that both species practice group-synchronous spawning (Wallace \& Selman 1981). A monthly profile of the oocyte maturity stage is depicted in Fig. 3. Mature and ripe Trichiurus lepturus females were found almost all year round and their spawning peaked from March to June. The dip found in August might be due to low sample size $(n=4)$. Mature and ripe $T$. nanhaiensis females were found from February to October; their peak spawning period lasted from April to August.

(A) T. lepturus

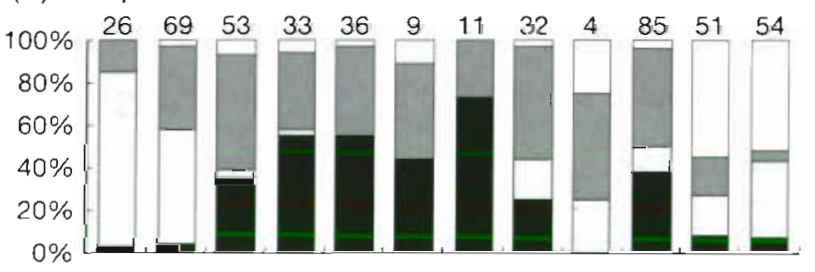

(B) T. nanhaiensis

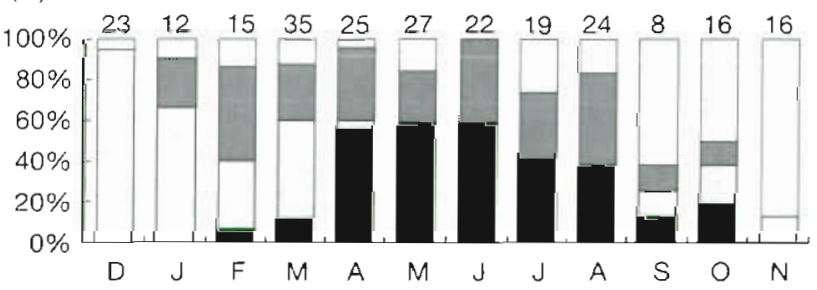

Fig. 3. Monthly profile of the whole oocyte maturity stage of cutlassfishes Trichiurus spp. The $x$-axes are months of collection, $y$-axes are percentage of ovaries at different maturity stages, numbers on the top are sample sizes. Maturity stages: black, Stage 3B and 4 (mature and spawning); light grey, Stage 1-2B (previtellogenic and early vitellogenic); dark grey, Stage 3A (advanced vitellogenic); white, Stage 5 and 6 (spent and atresia). Maturity stages follow Table 2

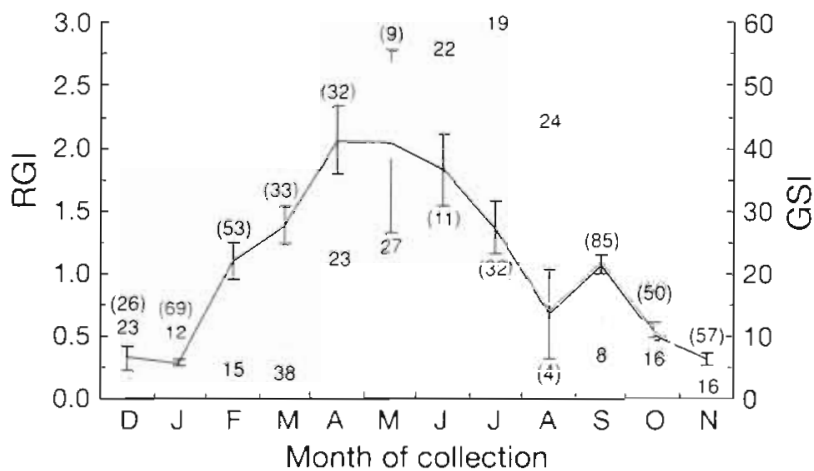

Fig. 4. Monthly variation in the gonad indices of female cutlassfishes Trichiurus spp. Black line: relative gonadal index (RGI) $\pm S E$ of $T$. lepturus, numbers in parentheses are sample sizes of $T$. lepturus. Grey line: gonosomatic index (GS1) \pm SE of $T$ nanhaiensis, numbers without parentheses are sample sizes of $T$. nanhaiensis

The monthly variation in the relative gonadal index (RGI) of Trichiurus lepturus females and in the gonosomatic index (GSI) of T. nanhaiensis females (Fig. 4) indicates that the peak spawning periods of $T$. lepturus and $T$. nanhaiensis were April to June and May to August respectively.

\section{Size at sexual maturity}

The results of regressions between $\ln [(1-P) / P]$ and $L$ are as follows:

Trichiurus Iepturus:

$$
\begin{aligned}
& \ln [(1-P) / P]=0.0227 L-5.785 \\
& \left(\mathrm{n}=319, \mathrm{R}^{2}=0.746, \mathrm{p}<0.001\right) ; \\
& \ln [(1-P) / P]=0.0126 L-3.539 \\
& \left(\mathrm{n}=249, \mathrm{R}^{2}=0.427, \mathrm{p}<0.05\right)
\end{aligned}
$$

T nanhaiensis:

Mean preanal lengths at sexual maturity $\left(L_{m}\right)$ of $T$. lepturus and $T$. nanhaiensis females were $255 \mathrm{~mm}$ (8.5 mo old; estimated using von Bertalanffy growth equations derived from a growth study [Kwok 1998|) and $282 \mathrm{~mm}$ (12 mo old; estimated using von Bertalanfy growth equations derived from a growth study [Kwok 1998]) respectively (Fig. 5). The minimum preanal length at sexual maturity of $T$. lepturus females was $185 \mathrm{~mm}$ while it could not be estimated for $T$. nanhaiensis females due to lack of juveniles.

\section{Sex and species ratio}

For both species, a chi-square analysis indicated significant deviation from a 1:1 sex ratio among different months (Trichiurus lepturus: $\chi_{11}^{2}=263.37, \mathrm{n}=595, \mathrm{p}<$ 0.001; T. nanhaiensis: $\chi_{11}^{2}=21.07, \mathrm{n}=525, \mathrm{p}<0.05$ ) different ages (T. lepturus: $\chi^{2}{ }_{5}=247.13, \mathrm{n}=832, \mathrm{p}<$ 
0.001; T. nanhaiensis: $\left.\chi^{2}{ }_{5}=22.91, \mathrm{n}=523, \mathrm{p}<0.05\right)$ and different size ranges ( $T$. lepturus: $\chi^{2}{ }_{7}=308.69, \mathrm{n}=938$, $\mathrm{p}<0.001$; T. nanhaiensis: $\left.\chi^{2}{ }_{5}=41.72, \mathrm{n}=535, \mathrm{p}<0.05\right)$. When only the spawning period was considered (spawning period for $T$. lepturus and $T$ nanhaiensis was March to June and April to August respectively), the sex ratio of $T$. nanhaiensis did not significantly deviate from the ratio of $1: 1$ (T. lepturus: $\chi^{2}{ }_{3}=35.72, \mathrm{n}$ $=131, \mathrm{p}<0.001 ; T$. nanhaiensis: $\chi_{4}^{2}=5.9, \mathrm{n}=237, \mathrm{p}>$ 0.37 ). For $T$, nanhaiensis, classes of larger sizes (PL $>$ $400 \mathrm{~mm}$ ) and older ages (age 25 ) were comprised mainly of female fish. For $T$, lepturus, however, females outnumbered males for most size and age classes. Furthermore, the 2 species mixed together throughout the whole collection period and the overall ratio was $1.79: 1$ ( $T$. lepturus: $T$. nanhaiensis) which was significantly different from the ratio $1: 1\left(\chi^{2}{ }_{1}=340.86\right.$, $n=1495, p<0.001$ ).

\section{DISCUSSION}

\section{Reproductive cycle and spawning period}

The accuracy of macroscopic staging of ovaries was found to be reasonably high (about $85 \%$ ) when compared with the results of whole oocyte examination. Most of the discrepancy came from the staging of spent ovaries. After the first spawning, the spent ovaries contain oocytes at less advanced maturity stages, which will develop and contribute to another spawning. This can only be revealed by whole oocyte examination. Ovary macroscopic examination is less time consum ing but it requires some experience and sometimes the staging can be quite subjective and uncertain. Further-

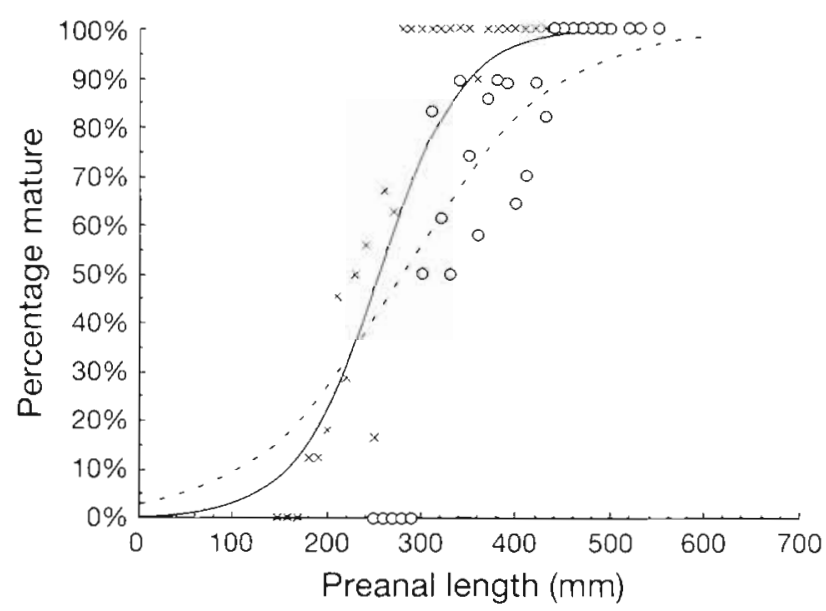

Fig. 5. Proportion mature versus preanal length of female cutlassfishes Trichiurus spp. Solid line (regression line) and crosses (raw data): T. lepturus. Dotted line (regression line) and circles (raw data): T. nanhaiensis more, macroscopic examination of ovaries does not permit us to address other topics such as detailed descriptions of development stage, atresia, and minimum size at sexual maturity (West 1990).

In comparison with macroscopic ovary observations, the whole oocyte examination was more accurate in staging the development of ovaries. The accuracy is attributed to the characteristics of the oocytes of these species - for example the clarity of the oocyte and its content, fusion of yolk globules and subsequent increased transparency, an ultimate large oil droplet and oocyte expansion induced by hydration. Unlike the histological study, this method failed to identify some stages and features: chromatin nucleolar stage; yolk vesicle (cortical alveoli); structure of follicular layer; nucleus after vitellogenesis, and its subsequent migration and breakdown. Another difficulty associated with the whole oocyte examination method is the identification of empty follicles which indicate recent spawning. Identification of the spent/spawned stage, however, can be assisted by macroscopic examination of the ovary, which provides a more discrete appearance: spent ovaries are pale violet in color, shrunk, and flaccid. During early months of the spawning period, April to June, spent ovaries staged by gonad macroscopic examination contained oocytes at less advanced maturity stages. These oocytes probably would ripen in 1 to 2 mo (Li 1982, Gong et al. 1984) and contribute to a second spawning.

This is the first time that the gonad indices have been validated in studying the reproduction of cutlassfish. In this study, GSI was proven inappropriate, at least for the specimens collected. When validated, nevertheless, gonad indices (RGI and GSI) can be good and objective indicators of seasonal trends for gonad development (West 1990). This was supported by the fact that findings from gonad indices agreed with the ovary examination and whole oocyte examination in this study. In this study, both GSI and RGI were found inapplicable for Trichiurus nanhaiensis. In order to compare the gonad indices monthly profile of both species, GSI was chosen for $T$. nanhaiensis. Because the majority of the specimens were within a reasonably narrow size range, the size dependent effect of GSI was reduced. In fact, the result agreed with those from ovary examination and whole oocyte examination.

In the East China Sea, Trichiurus lepturus possesses a protracted spawning period (April to October). This is because the East China Sea populations are composed of 2 brood stocks, i.e. spring-summer spawners and autumn spawners ( $L i$ 1982), and the former one might spawn twice per year (Li 1982, Gong et al. 1984). However, there is only 1 spawning population per species in this study area (Kwok 1998). Furthermore, spawning season may vary from year to year (El- 
Haweet \& Ozawa 1996). In the South China Sea, the spawning season is also very long, from February to October (from this study). This agrees with Chen \& Liu (1982). The spawning periods derived from the 3 different methods are very similar. Based on whole oocyte examination, both species may spawn twice in the same spawning season. This can explain why cutlassfishes demonstrate a protracted spawning period in the South China Sea, In general, the South China Sea cutlassfishes (in this study) spawn a little earlier than their northern counterparts. This may be due to the fact that the South China Sea has a warmer seawater temperature.

\section{Size at sexual maturity}

The decline in the age and size at sexual maturity and the biological minimum size of females at first maturity in the northern seas of China might have been a result of heary exploitation since size selective fishing would favor early maturity (Smith 1994). However, temporal variation of size and/or age at sexual maturity cannot be evaluated for the South China Sea populations due to the lack of historical data. In this study, the sizes of both species at sexual maturity are larger than those of their northern counterparts. This may be due to light fishing pressure or differences among populations. Nevertheless, the delineation of sexually mature individuals and the estimation method employed may be different, rendering the comparison less accurate. In this study. Trichiurus lepturus mature sexually at shorter lengths (PL) and earlier than T. nanhaiensis. Both species are capable of spawning in the year after hatching.

\section{Sex and species ratio}

In general, the number of female cutlassfish increased with size and age, which was also the case for cutlassfish in the northern seas (Suzuki \& Kimura 1980, Hanabuchi 1989). The growth coefficients $(k)$ are significantly different between sexes for both species; Trichiurus lepturus males possess lower growth coefficient than females, while the opposite is true for $T$. nanhaiensis (Kwok 1998). Therefore, growth rate cannot explain the skewed sex ratio. The sex ratio deviated from 1:1 for the whole study period. Whether these deviations (sex ratio among different ages, size ranges and months) were related to spatial variation as demonstrated by Munekiyo \& Kuwahara (1984b) and/or temporal variation remains a question for further investigation. An understanding of the spatial distribution and abundance (or relative abundance) of both $T$. lepturus and $T$. nanhaiensis are a prerequisite in revealing the species ratio.

\section{Recommendation}

The findings of this study provide some vital statistics useful in conducting the stock assessment. However, further investigations are needed to add to our understanding of the reproduction of cutlassfishes Trichiurus spp. from the South China Sea. Future research may include (1) the histological examination of male fishes to determine the reproductive cycle, which has not been investigated before even for the northern populations; (2) estimation of the relative fecundity and testing the correlation with the recruitment model; and (3) conducting artificial fertilization and rearing the larvae in captivity to find out whether the 2 species can cross-breed, and studying the early life history and development.

Acknowledgements. Helpful assistance offered by technician Mr Agassi Cheung and Ms Y. K. Tam was much appreciated. We thank V. A. Unkefer for technical writing assistance. We thank B. C. Collette and 3 anonymous reviewers for comments which led to significant improvements in the paper We also thank the Biology Department of the Hong Kong University of Science and Technology for providing necessary funding and facilities.

\section{LITERATURE CITED}

Chen ZC, Liu JQ (1982) Commercial fishes of South China Sea. Guangdong Science and Technology Press, Guangzhou, p 208-215 (in Chinese)

DeVlaming V, Grossman G, Chapman F (1982) On the use of the gonosomatic index. Comp Biochem Physiol 73A(1): $31-39$

El-Haweet AE, Ozawa T (1996) Age, growth of ribbon fish Trichiurus japonicus in Kagoshima Bay, Japan. Fish Sci 62(4):529-533

Erickson DL, Hightower JE, Crossman GD (1985) The relative gonadal index: an alternative index for quantification of reproductive condition. Comp Biochem Physiol 81A(1): $117-120$

Gong Q, Jia G, Wang P, Yian J, Du L (1984) On the cytological changes of the ovaries of hairtails Trichiurus haumela (Forskall) in the Dong Hai Sea. J Fish China 8(3):185-196 (in Chinese with English abstract)

Hanabuchi S (1989) Age and growth of cutlassfish. Trichiurus lepturus in Tsushima waters. Bull Seikai Reg Fish Res Lab 67:37-57 (in Japanese with English abstract)

Jiang SF, Wang XZ, Chen YD, Zeng XQ (eds) (1991) Compilation of the statistics of Chinese Fishery for forty years (1949-1988). Department of Fishery, Ministry of Agriculture, The People's of Republic China. China Ocean Press, Beijing, p 14-16 (in Chinese)

King MG (1995) Fisheries biology, assessment and management. Fishing News Books, Cornwall

Kosaka M, Ogura M, Shirai H, Maeji M (1967) Ecological study on the ribbon Fish. Trichiurus lepturus Linne, in 
Suruga Bay. J Coll Mar Sci Technol Tokai Univ 2:131-146 (in Japanese with English abstract)

Kwok KY (1998) Reproduction and growth of cutlassfishes, Trichiurus spp. from the South China Sea. MPhil thesis, The Hong Kong University of Science \& Technology

Li C (1982) Annual ovarian changes of Trichiurus haumela in the East China Sea. Oceanologia Limnol Sin 13(5):461-472 (in Chinese with English abstract)

Li C (1983) A study on the individual fecundity and its dynamics of Trichiurus haumela (Forskål) of the East China Sea. Oceanologia Limnol Sin 14(3):220-239 (in Chinese with English abstract)

Li C (1986) Annual variations in the individual fecundity of hairtail from the East China Sea. Oceanologia Limnol Sin 17(Suppl):207-218 (in Chinese with English abstract)

Li C (1988) A comparison of fecundity of spring and autumnspawning groups of Trichiurus haumela (Forskål) from the East China Sea. Oceanologia Limnol Sin 19(2):116-124 (in Chinese with English abstract)

Lin JQ (1982) On the cause of prematuration of the East Sea hairtail (Trichiurus haumela). Mar Fish Res 4:9-15 (in Chinese with English abstract)

Lin JQ (1985) Hairtails. Agriculture Press, Beijing (in Chinese)

Luo B (1991) Cutlassfish. In: Fan CQ (ed) Marine fishery biology, Agriculture Press, Beijing, p 111-160 (in Chinese)

Luo B, Lu J, Huang S (1982) The identification of different season of brood in hairtails, Trichiurus haumela (Pisces, Trichiuridae). Oceanologia Limnol Sin 13(5):451-460 (in Chinese with English abstract)

Luo B, Lu J, Huang S (1983) Maturation of the hairtails, Trichiurus haumela (Pisces, Trichiuridae) I. The process of maturation and peculiarities of the female. Oceanologia Limnol Sin 14(1):54-63 (in Chinese with English abstract)

Misu $\mathrm{H}$ (1964) Fisheries biology on the ribbon fish (Trichiurus lepturus Linne) in the East China and Yellow Seas. Bull Seikai Reg Fish Res Lab 32:1-58 (in Japanese with English abstract)

Munekiyo M, Kuwahara A (1984a) Spawning season and sex ratio of ribbon fish in the western Wakasa Bay. Bull Jpn Soc Sci Fish 50(8):1279-1284 (in Japanese with English abstract)

Munekiyo M, Kuwahara A (1984b) Spawning ground, mating systems and distribution pattern of ribbon fish. Bull Jpn Soc Sci Fish 50(9):1527-1533 (in Japanese with English abstract)

Munekiyo M, Kuwahara A (1988) Maturity and spawning of ribbon fish in the western Wakasa Bay. Bull Jpn Soc Sci Fish 54(8):1315-1320 (in Japanese with English abstract)

Ni IH. Sandeman EJ (1984) Size at maturity for Northwest

Editorial responsibility: Kenneth Sherman (Contributing Editor), Narragansett, Rhode Island, USA
Atlantic redfishes (Sebastes). Can J Fish Aquat Sci 41. $1753-1762$

$\mathrm{Ni}$ IH, Templeman W (1985) Reproductive cycles of redfishes (Sebastes) in southern Newfoundland waters. J Northwest Atl Fish Sci 6:57-63

Park CS, Hwang BN (1978) A study on the maturity and spawning of hair tail, Trichiurus lepturus Linne in the south-western waters of Korea. Bull Fish Res Dev 20: 51-56 (in Korean with English abstract)

Qiu W, Jiang D (1965) A study of the individual fecundity of Trichiurus haumela (Forskål) of East China. Oceanologia Limnol Sin 2(2):13-25 (in Chinese with English abstract)

Sakamoto T (1976) Age and growth of the ribbon fish in the Kii Channel. Bull Jpn Soc Sci Fish 42(1):1-11 (in Japanese with English abstract)

Sha XS, Ruan H, He G (1981) A description of the morphological characteristics of the eggs and larvae of the hairtails, Trichiurus haumela (Forskål). J Fish China 5(2):155-160 (in Chinese with English abstract)

Smith PJ (1994) Genetic diversity of marine fisheries resources: possible impacts of fishing. FAO Fisheries Technical Paper 344. Food and Agriculture Organization of the United Nations, Rome

Suzuki K, Kimura S (1980) Fishery biology of the ribbon fish, Trichiurus lepturus, in Kumano-Nada, central Japan. Faculty of Fish Mie Univ 7:173-192 (in Japanese with English abstract)

Tsukahara H (1961) Biology of the cutlassfish, Trichiurus lepturus Linnaeus. Rec Oceanogr Works Jpn 5:117-121

Wallace RA, Selman K (1981) Cellular and dynamic aspects of oocyte growth in teleosts. Am Zool 21:325-343

Wang K, Liu L, You F, Xu C (1992) Studies on the genetic variation and systematics of the hairtails fishes from South China Sea. Mar Sci 2:69-71 (in Chinese with EngIish abstract)

Wang K, Zhang P, Liu L, You F, Xu C (1993) Studies on Trichiuridae from China coastal water. Acta Oceanologica Sinica Vol 15 No 2 (in Chinese)

Wang K, Zhang P, Liu L, You F, Xu C, Wang JF (1994) Biochemical assessment of the taxonomic status of Trichiuridae population from China Coastal water. Acta Oceanologica Sinica Vol 16 No 1 (in Chinese)

West $G(1990)$ Methods of assessing ovarian development in fishes: a review. Aust J Mar Freshw Res 4 1:199-222

Xu H, Liu Z, Ding Y, Xu Y (1994) Resources condition and management countermeasure of largehead hairtail in East China Sea. J Zhejiang Fish Coll Bull 13(1):5-11 (in Chinese with English abstract)

Ye Y, Rosenberg AA (1991) A study of the dynamics and management of the hairtail fishery, Trichiurus haumela, in the East China Sea. Aquat Living Resour 4(2):65-75

Submitted: June 15, 1998; Accepted: October 20,1998

Proofs received from author(s): January 15, 1999 